O. KIRRET, P.-A. KOCH, Lilja LAHE,

G. RAJALO, Ene KIRJANEN

\title{
CHARACTERIZATION AND IDENTIFICATION OF CHEMICAL AND NATURAL FIBRES \\ BY INFRARED SPECTROSCOPIC METHOD AND COMPUTER
}

This work is a continuation of a series of articles on the characterization and identification of fibres by the infrared spectroscopic method $\left[{ }^{1-4}\right]$, infrared spectrometry and computer $\left[{ }^{5}\right]$.

In this paper data are presented about the characteristic properties of infrared spectra of chemical (propylene, polytetrafluoroethylene, polyvinyl alcohol-acetal, viscose, cellulose ester) and natural (cotton, wool and silk) fibres (belonging of absorption bands to one or other atomic group vibration and their intensities). We present here the infrared spectra of their absorption bands as well as intensities of the above fibres.

It should also be noted that we deal mainly with chemical and natural fibres important from the viewpoint of manufacturing textile fabrics.

Polypropylene fibres. K. Ziegler's discovery of organic catalysis of transitional metals for low-temperature and pressure polymerization of alkenes and G. Natta's discovery of stereospecific catalysis permitted, in 1954 , the preparation of isotactic polypropylene via polymerization of propylene [ ${ }^{9}$ ]. At the preparation of polypropylene, besides isotactic polypropylene, also atactic polypropylene is formed, being extracted as an undesirable by-product with boiling $n$-heptane.

According to K. Ziegler, the polypropylene mole mass is 40,000 , boiling point $176^{\circ} \mathrm{C}$, density $0.90 \mathrm{~g} / \mathrm{cm}^{3}\left[{ }^{6}\right]$. The isotactic polypropylene alone is fit for the preparation of polypropylene fibre. The 1980 world output of polypropylene amounted to 5 million tons, $28 \%$ of which have been used for manufacturing textile fabrics, carpets and sacking.

In the case of strong and very strong absorption bands of infrared spectra of fibres our data correlated(Table 1) well with those given in $\left[{ }^{7}\right]$. At the assignment of vibrations of the atomic groups, data have been taken from the literature. The most characteristic absorption bands of infrared spectra of polypropylene are $841,842,974,975,998, ' 1168,1170$, $1376,1380,1455,1457,1465,2879,2920$, and $2960 \mathrm{~cm}^{-1}$.

Polytetrafluoroethylene fibres. According to the known method, the monomer tetrafluoroethylene is polymerized in stainless steel autoclaves under pressure in the presence of ammonium peroxydisulphate as a freeradical initiator. The granules formed are collected, washed and dried. The polymer is further extruded $\left.{ }^{6}\right]$. The density of polytetrafluoroethylene is $2.1-2.3$, the melting point of the crystalline product is $327^{\circ}$. The polymer is not soluble in conventional solvents. The infrared spectrum of polytetrafluoroethylene contains three strong absorption 
Absorption bends of infrared spectra of polypropylene fibres, $\mathrm{cm}^{-1}$

\begin{tabular}{|c|c|c|c|}
\hline $\begin{array}{c}\text { Polypro- } \\
\text { pylene } \\
\text { (USSR) }\end{array}$ & $\begin{array}{c}\text { Meraklon } \\
\text { (Italy) }\end{array}$ & $\begin{array}{l}\text { Relative } \\
\text { intensity }\end{array}$ & Assignment [p] \\
\hline 809 & 810 & w & $v_{\mathrm{s}}(\mathrm{CC}) ; \mathrm{r}\left(\mathrm{CH}_{2}\right)$ \\
\hline 841 & 842 & $\mathrm{~m}$ & $\mathrm{r}(\mathrm{CH})$ \\
\hline 900 & 900 & w & $v_{8}(\mathrm{CC}) ; \mathrm{r}_{\mathrm{b}}\left(\mathrm{CH}_{3}\right)$ \\
\hline 940 & 940 & vw & $\mathrm{r}_{\mathrm{a}}\left(\mathrm{CH}_{3}\right) ; \mathrm{r}_{\mathrm{b}}\left(\mathrm{CH}_{3}\right) ; v_{\mathrm{b}}(\mathrm{CC})$ \\
\hline 974 & 975 & $\mathrm{~m}$ & $v_{\mathrm{a}}\left(\mathrm{CH}_{3}\right) ; v_{\mathrm{b}}(\mathrm{CC})$ \\
\hline 998 & 998 & $\mathrm{~m}$ & $\mathrm{r}_{\mathrm{b}}\left(\mathrm{CH}_{3}\right)$ \\
\hline $\begin{array}{l}1045 \\
1100\end{array}$ & $\begin{array}{l}1045 \\
1100\end{array}$ & vw & $v_{\mathrm{a}}(\mathrm{CC})$ \\
\hline 1168 & 1170 & m & $v_{\mathrm{b}}(\mathrm{CC})-\mathrm{r}_{\mathrm{a}}\left(\mathrm{CH}_{3}\right)$ \\
\hline 1255 & 1258 & w & $\mathrm{t}\left(\mathrm{CH}_{2}\right)$ \\
\hline 1305 & 1308 & w & $\omega\left(\mathrm{CH}_{2}\right)+\delta(\mathrm{CH})$ \\
\hline 1330 & & vw & $\omega(\mathrm{CH})-v_{\mathrm{b}}(\mathrm{CC})$ \\
\hline 1358 & 1360 & w & $\delta(\mathrm{CH})-\mathrm{w}\left(\mathrm{CH}_{2}\right)$ \\
\hline $\begin{array}{l}1376 \\
1455\end{array}$ & $\begin{array}{l}1380 \\
1457\end{array}$ & s & $\delta\left(\mathrm{CH}_{3}\right)$ \\
\hline $\begin{array}{l}1455 \\
1465\end{array}$ & $\begin{array}{l}145 \% \\
1465\end{array}$ & $\begin{array}{l}\mathrm{s} \\
\mathrm{s}\end{array}$ & $\begin{array}{l}\delta\left(\mathrm{CH}_{3}\right) \\
\delta\left(\mathrm{CH}_{3}\right)\end{array}$ \\
\hline 2723 & 2725 & w & \\
\hline $\begin{array}{l}2836 \\
2879\end{array}$ & $\begin{array}{l}2836 \\
2870\end{array}$ & s & $v_{\mathrm{s}}\left(\mathrm{CH}_{2}\right)$ \\
\hline $\begin{array}{l}2879 \\
2920\end{array}$ & $\begin{array}{l}2879 \\
2920\end{array}$ & $\begin{array}{l}\mathrm{s} \\
\mathrm{s}\end{array}$ & $\begin{array}{l}v_{8}\left(\mathrm{CH}_{3}\right) \\
v_{\mathrm{as}}\left(\mathrm{CH}_{2}\right)\end{array}$ \\
\hline 2960 & 2960 & s & $v_{\mathrm{as}}\left(\mathrm{CH}_{3}\right)$ \\
\hline
\end{tabular}

Table 2

Absorption bands of infrared spectra of polytetrafluoroethylene fibres, $\mathrm{cm}^{-1}$

\begin{tabular}{|c|c|c|}
\hline Teflon (USA) & $\begin{array}{l}\text { Polyphene } \\
\text { (USSR) }\end{array}$ & Assignment $\left[{ }^{7}\right]$ \\
\hline $\begin{array}{l}500 \\
555 \\
625 \\
640 \\
720 \\
740 \\
770-780 \\
1020 \\
1070 \\
1155 \\
1200-1250\end{array}$ & $\left.\begin{array}{r}500 \\
555 \\
625 \\
645 \\
720 \\
740 \\
770-780 \\
1020 \\
1070 \\
1155 \\
1200-1250\end{array}\right\}$ & $\begin{array}{l}\mathrm{w}\left(\mathrm{CF}_{2}\right) ; \delta\left(\mathrm{CF}_{2}\right) \text { specific for crystal structure } \\
\text { specific for amorphous structure } \\
v\left(\mathrm{CF}_{2}\right)\end{array}$ \\
\hline
\end{tabular}

bands (Table 2) in the regions 555,625 and $640 \mathrm{~cm}^{-1}$, which are characteristic of the $\mathrm{CF}_{2}$ rocking and bending vibration as well as of the crystalline structure. The weak absorption bands $720,740,770-780 \mathrm{~cm}^{-1}$ are typical of the amorphous structure.

The absorption bands 1155 and $1200-1250 \mathrm{~cm}^{-1}$ correspond to the $\mathrm{CF}_{2}$ stretching vibration. The above absorption bands $555,625,640,720$, $740,770-780,1155,1200-1250 \mathrm{~cm}^{-1}$ are most characteristic of polytetrafluoroethylene.

Polyvinyl alcohol (-acetal) fibres. Due to its low stability, polyvinyl alcohol cannot be obtained by polymerization of monomeric vinyl alcohol. Polyvinyl alcohol is prepared indirectly by saponification of polyvinyl acetate, different by-products being formed besides the main product, depending upon the degree of polymerization [ $\left.{ }^{7}\right]$. The fibres prepared from polyvinyl alcohol are insoluble in water, In order to 
Table 3

Absorption bands of infrared spectra of polyvinylalcohol(-acetal) fibres, $\mathrm{cm}^{-1}$

\begin{tabular}{|c|c|c|c|c|c|}
\hline Vinol (USSR) & $\begin{array}{l}\text { Kuralon } \\
\text { (Japan) }\end{array}$ & $\begin{array}{l}\text { Vinylon } \\
\text { (Japan) }\end{array}$ & Solfon (FRG) & 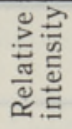 & Assignment $\left[{ }^{7}\right]$ \\
\hline 800 & 800 & 800 & - & w & \\
\hline 850 & 845 & 850 & 850 & $\mathrm{~s}$ & $\delta\left(\mathrm{CH}_{2}\right)$ \\
\hline 920 & 920 & 920 & 920 & w & \\
\hline 1020 & 1020 & 1020 & - & $\mathrm{s}$ & \\
\hline 1070 & 1070 & 1070 & - & $\mathrm{s}$ & $v(\mathrm{CC})$ \\
\hline 1100 & 1100 & 1100 & 1100 & vs & $v(\mathrm{CO}) ; \gamma(\mathrm{OH}) \mathrm{sec}$ \\
\hline 1145 & 1145 & 1145 & 1145 & $\mathrm{~m}$ & ** \\
\hline 1180 & 1180 & 1177 & - & $\mathrm{s}$ & $v(\mathrm{CC})$ \\
\hline 1240 & 1240 & 1240 & 1237 & vs & $\delta(\mathrm{CH})$ \\
\hline 1330 & 1330 & 1330 & 1330 & $\mathrm{~m}$ & $\delta(\mathrm{CH})$ \\
\hline $1360-1395$ & $1360-1395$ & $1360-1395$ & $1360-1385$ & w & \\
\hline 1415 & 1415 & 1415 & 1415 & $\mathrm{~m}$ & \\
\hline 1445 & 1445 & 1445 & 1445 & $\mathrm{~m}$ & $\delta\left(\mathrm{CH}_{2}\right)$ \\
\hline 1480 & 1480 & 1475 & 1475 & $\mathrm{~m}$ & \\
\hline- & - & 1640 & $1640 \mathrm{vw}$ & w & \\
\hline 1715 & 1715 & 1715 & 1710 & $\mathrm{~m}$ & \\
\hline 1730 & 1725 & 1725 & 1730 & $\mathrm{~m}$ & $v(\mathrm{C}=\mathrm{O})$ \\
\hline 2775 & 2775 & 2775 & - & & $2 \times 1387$ \\
\hline 2865 & 2860 & 2860 & 2860 & vs & $v\left(\mathrm{CH}_{2}\right)$ \\
\hline 2910 & $2910^{\circ}$ & 2910 & 2910 & $\mathrm{~s}$ & $v(\mathrm{CH})$ \\
\hline 2940 & 2940 & 2940 & 2940 & vs & $v(\mathrm{CH})$ \\
\hline 3400 & 3400 & 3400 & 3400 & s & $v(\mathrm{OH})$ \\
\hline
\end{tabular}

* syndiotactic configuration, ** cristallinity band.

Table 4

Absorption bands of infrared spectra of wool fibres, $\mathrm{cm}^{-1}$

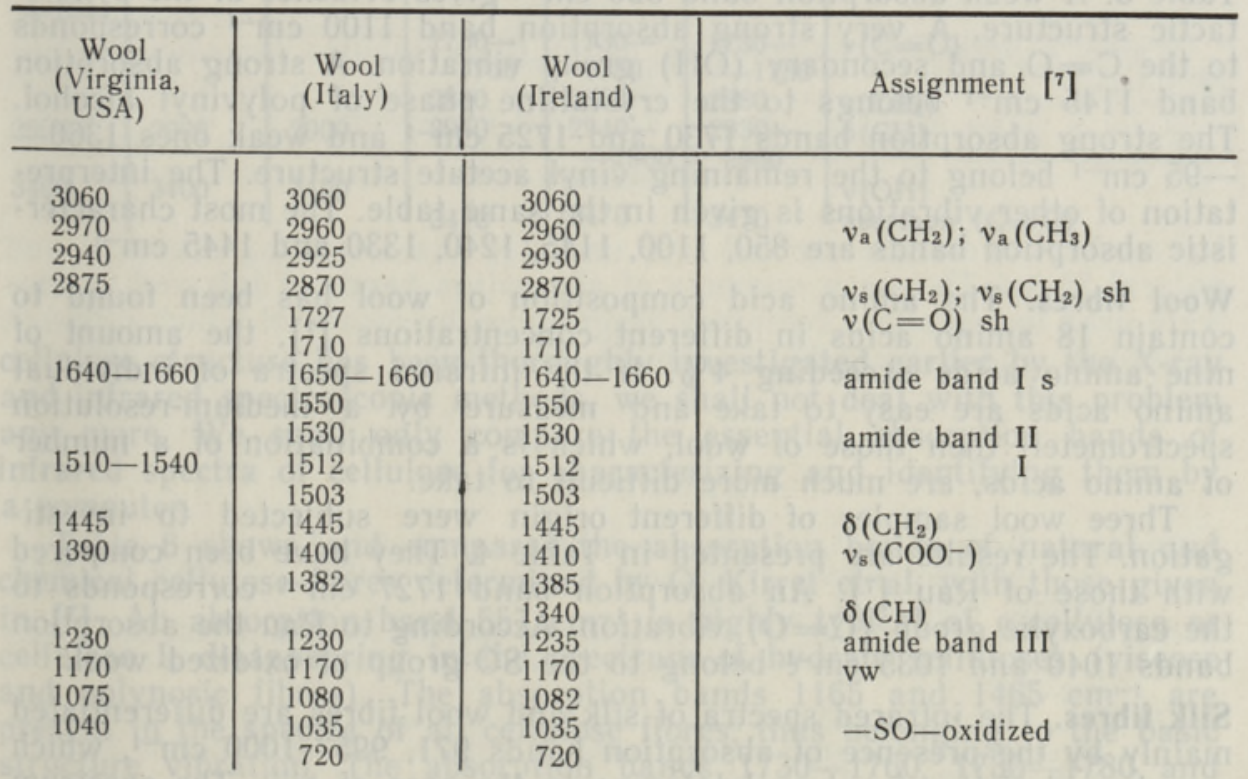

obtain water soluble fibres, polyvinyl alcohol fibres are treated with formaldehyde (acetalized), approximately $35-40 \%$ of the OH-groups being replaced by acetal $\left(-\mathrm{O}-\mathrm{CH}_{2}-\mathrm{O}\right)$ groups $\left[{ }^{8}\right]$. The interpretation of absorption bands of infrared spectra of polyvinyl alcohol is given in 
Absorption bands of infrared spectra of silk fibres, $\mathrm{cm}^{-1}$

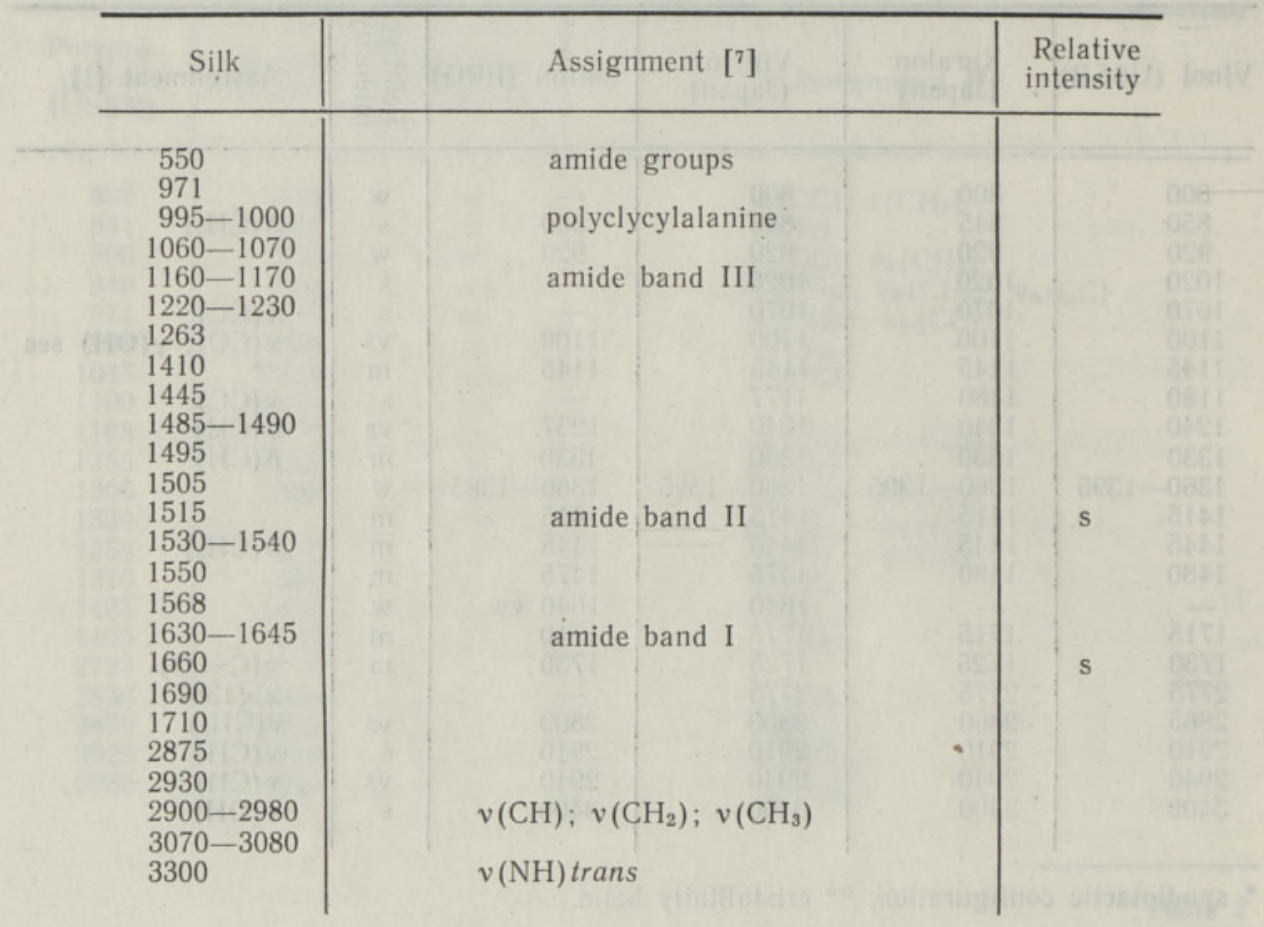

Table 3. A weak absorption band $920 \mathrm{~cm}^{-1}$ gives evidence of the syndiotactic structure. A very strong absorption band $1100 \mathrm{~cm}^{-1}$ corresponds to the $\mathrm{C}=\mathrm{O}$ and secondary $(\mathrm{OH})$ group vibration. A strong absorption band $1145 \mathrm{~cm}^{-1}$ belongs to the crystalline phase of polyvinyl alcohol. The strong absorption bands 1730 and $1725 \mathrm{~cm}^{-1}$ and weak ones 1360 $-95 \mathrm{~cm}^{-1}$ belong to the remaining vinyl acetate structure. The interpretation of other vibrations is given in the same table. The most characteristic absorption bands are $850,1100,1145,1240,1330$ and $1445 \mathrm{~cm}^{-1}$.

Wool fibres. The amino acid composition of wool has been found to contain 18 amino acids in different concentrations $\left[{ }^{7}\right]$, the amount of nine amino acids exceeding $4 \%$. If the infrared spectra of individual amino acids are easy to take and measure by a medium-resolution spectrometer, then those of wool, which is a combination of a number of amino acids, are much more difficult to take.

Three wool samples of different origin were subjected to investigation. The results are presented in Table 4 . They have been compared with those of $\mathrm{Rau}\left[{ }^{7}\right]$. An absorption band $1727 \mathrm{~cm}^{-1}$ corresponds to the carboxylic group $(\mathrm{C}=\mathrm{O})$ vibration. According to Rau the absorption bands 1040 and $1035 \mathrm{~cm}^{-1}$ belong to the SO-group of oxidized wool.

Silk fibres. The infrared spectra of silk and wool fibres are differentiated mainly by the presence of absorption bands $971,995-1000 \mathrm{~cm}^{-1}$, which are characteristic of polycyclylalanine in the case of silk. The spectrum of wool contains no such bands. An absorption band $550 \mathrm{~cm}^{-1}$ in the infrared region is also typical of silk, indicating the presence of amido groups. The absorption bands of silk somewhat coincide with those reported by Rau (Table 5 ) $\left[{ }^{7}\right]$.

Cellulose fibres (cotton, viscose, polynose, cellulose esters). As the 
Table 6

Absorption bands of infrared spectra of cellulose and cellulose ester fibres, $\mathrm{cm}^{-1}$

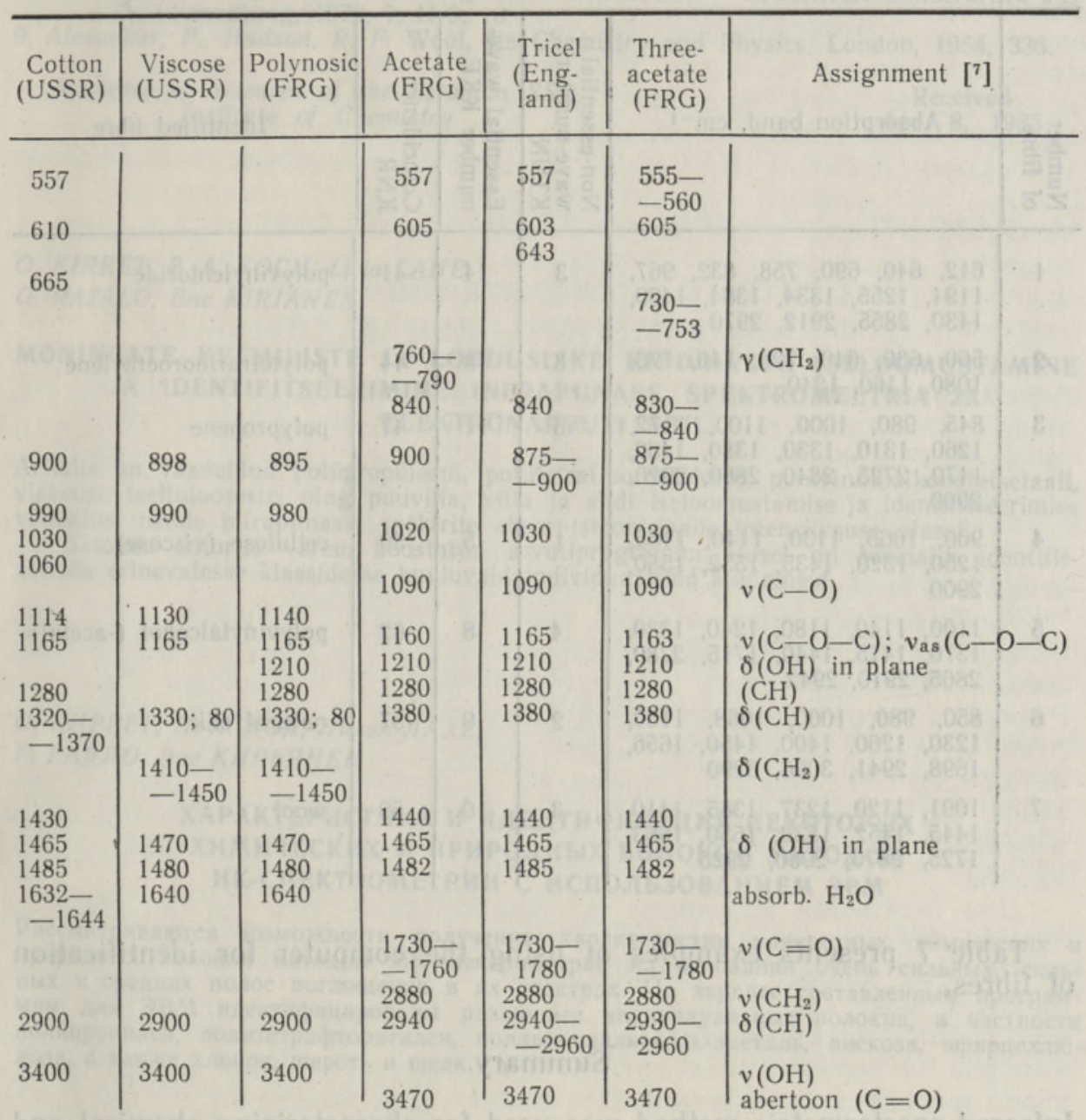

cellulose structure has been thoroughly investigated earlier by the X-ray and infrared spectroscopic methods, we shall not deal with this problem any more. We shall only compare the essential absorption bands of infrared spectra of cellulose for characterizing and identifying them by a computer.

Table 6 shows and compares the absorption bands of natural and chemical cellulose fibres determined by $\mathrm{O}$. Kirret et al. with those given in [7]. An absorption band $557 \mathrm{~cm}^{-1}$ is highly typical of $\alpha$-cellulose or cellulose I, disappearing in the spectrum of hydrate celluloses (viscose and polynosic fibres). The absorption bands 1165 and $1465 \mathrm{~cm}^{-1}$ are present in the spectra of all cellulose fibres, thus belonging to the basic structure vibration. The absorption bands $1730-1760,1730-1780$ and $2880 \mathrm{~cm}^{-1}$ are typical of cellulose ester fibres, corresponding to the $\mathrm{C}=\mathrm{O}$ vibration. The latter band is absent in the spectrum of cotton and viscose fibres. The cellulose fibres (cotton) are also characterized by the absorption bands $557,665,900,1165,1320,1465,1480$ and $1640 \mathrm{~cm}^{-1}$. The cellulose ester fibres are characterized by the absorption bands $557,605,840,900,1090,1165,1380,1465,1745$ and $2880 \mathrm{~cm}^{-1}$. 
Some examples for identification of chemical and natural fibres with computer

\begin{tabular}{|c|c|c|c|c|c|c|}
\hline 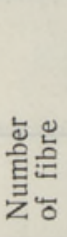 & Absorption band, $\mathrm{cm}^{-1}$ & 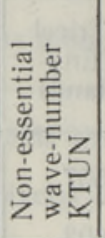 & 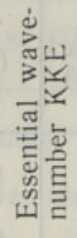 & 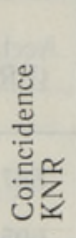 & \multicolumn{2}{|c|}{ Identified fibre } \\
\hline 1 & $\begin{array}{l}612,640,690,758,832,967, \\
1194,1255,1334,1384,1430 \\
1430,2855,2912,2970\end{array}$ & 3 & 14 & 41 & polyvinylchloride & \\
\hline 2 & $\begin{array}{l}560,630,640,725,740,775 \\
1080,1160,1240\end{array}$ & 3 & 8 & 44 & polytetrafluoroethy & ylene \\
\hline 3 & 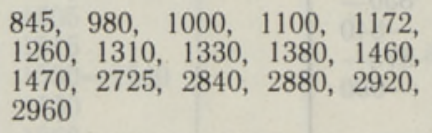 & 5 & 11 & 47 & polypropene & \\
\hline 4 & $\begin{array}{l}900,1065,1130,1140,1165, \\
1250,1320,1435,1532,1550, \\
2900\end{array}$ & 1 & 5 & 50 & cellulose (viscose) & \\
\hline 5 & $\begin{array}{l}1100,1140,1180,1240,1330, \\
1370,1415,1440,1715,2780, \\
2865,2910,2942\end{array}$ & 4 & 8 & 62 & polyvinylalcohol & (-acetal) \\
\hline 6 & $\begin{array}{llll}850, & 980,1000, & 1068, & 1160, \\
1230,1260,1400, & 1450, & 1656, \\
1698, & 2941,3096, & 3290 & \end{array}$ & 2 & 9 & 57 & natural silk & \\
\hline 7 & 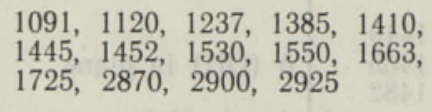 & 3 & 10 & 59 & wool & \\
\hline
\end{tabular}

Table 7 presents examples of using the computer for identification of fibres.

\section{Summary}

Infrared spectrometric method was used for characterizing chemical and natural fibres. The wave numbers of absorption bands of infrared spectra were used to compile a computer programme, by means of which different individual and natural fibres can be identified.

\section{REFERENCES}

1. Kirret, O., Pank, M., Lahe, L. Characterization and identification of polyester fibres and their modification by infrared spectrometric method. - ENSV TA Toim. Keemia, 1980, 29, N 2, 92-96.

2. Kirret, O., Koch, P.-A., Lahe, L. Characterization and identification of polyamide fibres by infrared spectrometric method. - ENSV TA Toim. Keemia, 1981, 30, N 4, $280-287$.

3. Kirret, O., Koch, P.-A., Lahe, L. Characterization and identification of polyvinylchloride fibres by infrared spectroscopic method. - ENSV TA Toim. Keemia, 1982, 31, $\mathrm{N} 1,50-53$.

4. Kirret, O., Koch, P.-A., Lahe, L. Characterization and identification of polyacrylonitrile fibres and their modifications and modacrylic fibres by infrared spectrometric method. - ENSV TA Toim. Keemia, 1982, 31, N 3, 197-203.

5. Kirret, O., Lahe, L., Rajalo, G., Kirjanen, E. Characterization and identification of chemical fibres by infrared spectrometric method and computer. - ENSV TA Toim. Keemia, 1983, 32, N 2, 119-124.

6. Saunders, K. J. Organic Polymer Chemistry. London, 1973, 52, 140. 
7. Hummel/Scholl. Atlas der Kunststoff-Analyse. München, 1968, Bd. I, T/I. 1, 131, 176, $102-104,111,154$.

8. Koch, P.-A., Stein, H. J. Die wichtigsten Chemiefasern. - Erweiterter Sonderdruck aus Textilveredlung, 1972, 7, N 9, 16.

9. Alexander, P., Hudson, R. F. Wool, Its Chemistry and Physics. London, 1954, 336.

Academy of Sciences of the Estonian SSR, Institute of Chemistry

Received

Apr. 8, 1983

O. KIRRET, P.-A. KOCH, Lilja LAHE,

G. RAJALO, Ene KIRJANEN

\section{MONINGATE KEEMILISTE JA LOODUSLIKE KIUDAINETE ISELOOMUSTAMINE JA IDENTIFITSEERIMINE INFRAPUNASE SPEKTROMEETRIA JA ELEKTRONARVUTI ABIL}

Artiklis on vaadeldud polüpropüleeni, polütetrafluoroetüleeni, polüvinüülalkoholatsetaali, viskoosi, tselluloosestri ning puuvilla, villa ja siidi iseloomustamise ja identifitseerimise võimalusi nende infrapunaste spektrite absorptsiooniribade intensiivsuse alusel.

Samade autorite varem koostatud arvutiprogrammi alusel on võimalik identifitseerida erinevatesse klassidesse kuuluvaid individuaalseid kiudaineid.

О. КИРРЕТ, П.-А. КОХ, ЛИЛЬЯ ЛАХЕ,

Г. РАЯЛО, Эне КИРЬЯНЕН

\section{ХАРАКТЕРИСТИКА И ИДЕНТИФИКАЦИЯ НЕКОТОРЫХ \\ ХИМИЧЕСКИХ И ПРИРОДНЫХ ВОЛОКОН МЕТОДОМ \\ ИК-СПЕКТРОМЕТРИИ С ИСПОЛЬЗОВАНИЕМ ЭВМ}

Рассматриваются возможности получения характеристик конкретных химических и природных волокон методом ИК-спектрометрии на основании очень сильных, сильных и средних полос поглощения в их спектрах. По заранее составленным программам для ЭВМ идентифицированы различные индивидуальные волокна, в частности полипропилен, политетрафторэтилен, поливинилалкоголь-ацеталь, вискоза, эфирцеллюлоза, а также хлопок, шерсть и шелк. 